\title{
ФОРМУВАННЯ НАВИЧОК ДІАЛОГІЧНОГО МОВЛЕННЯ СТУДЕНТІВ МЕДИЧНИХ СПЕЦІАЛЬНОСТЕЙ ПІД ЧАС ВИВЧЕННЯ КУРСУ «УКРАЇНСЬКА МОВА ЯК ІНОЗЕМНА»
}

\section{P. Sheremeta}

\section{Horbachevsky Ternopil State Medical University \\ FORMATION OF STUDENTS’ (MEDICAL SPECIALTIES) DIALOGIC SPEAKING SKILLS WHILE STUDYING THE UKRAINIAN LANGUAGE AS A FOREIGN}

\begin{abstract}
Анотація. У статті проаналізовано основні аспекти формування навичок діалогічного мовлення під час вивчення курсу «Українська мова як іноземна». Описано авторську методику засвоєння матеріалу, спрямовану на оптимальний відбір шляхів підвищення ефективності заняття. Подано методичні рекомендації щодо формування в іноземних студентів медичного профілю умінь і навичок діалогування.

Обгрунтовано, що система навчання українського діалогічного мовлення іноземців передбачає засвоєння мовно-мовленнєвих знань з української мови та формування комунікативних умінь та навичок, актуальних для послуговування в україномовному середовищі.

Доведено, що формування української мовленнєвої компетенції студентів-іноземців відбувається на основі мовної підготовки, що включає в себе вільне володіння професійною лексикою та обмін знаннями з медичних предметів, обговорення тем, дискутування з їх приводу.

Проаналізовані аспекти навчання діалогічного мовлення сприятимуть оптимізації процесу навчання іноземних студентів у вищих навчальних закладах України та можуть бути використані при подальшій розробці нових методик оцінювання рівня професійної підготовки майбутніх працівників медичного профілю.
\end{abstract}

Ключові слова: діалогічне мовлення; монологічне мовлення; методи і прийоми навчання; система вправ; українська мова як іноземна.

Abstract. The main aspects of the formation of dialogic skills during the course of Ukrainian as a Foreign Language are analyzed in the article. The author's method of mastering the material, aimed at the optimal selection of ways to improve the efficiency of the lesson, is described. Methodical recommendations are given for the development of a medical profile of foreign students in the medical profile of dialogue.

It is substantiated that the system of teaching Ukrainian dialogic speech of foreigners involves mastering the linguistic and spoken knowledge of the Ukrainian language and the formation of communicative skills relevant for service in the Ukrainian language environment.

It is proved that the formation of the Ukrainian language competence of foreign students is based on language training, which includes free fluency in professional vocabulary and exchange of knowledge in medical subjects, discussion of topics, discussion on their subject. The analyzed aspects of the teaching of dialogue speech will help to optimize the learning process of foreign students in higher education institutions. It is proved that the formation of the Ukrainian language competence of foreign students is based on language training, which includes free fluency in professional vocabulary and exchange of knowledge in medical subjects, discussion of topics, discussion on their subject.

The analyzed aspects of dialogic speech training will help to optimize the process of teaching foreign students in higher educational establishments of Ukraine and can be used in further development of new methods of assessing the level of professional training of future medical professionals.

Key words: dialogic speech; monologue speech; teaching methods and techniques; exercise system; Ukrainian as a foreign language.

Вступ. Інтеграція національної освіти на сучасному етапі передбачає широке використання нових

(ㄱ Л. П. Шеремета технологій, напрямів і прогресивних підходів до навчання. В умовах становлення Української Держави як рівноправного партнера у створенні сучасного 
освітнього простору важливим чинником виступає навчання іноземних студентів у вищих навчальних закладах України. Проблема володіння українською мовою як іноземною в системі освіти є актуальною, оскільки у ВНЗ України навчається значна кількість іноземних студентів, для яких українська мова виступає навчальним предметом й освітньою дисципліною, засобом всебічного розвитку, провідником у становленні їх як професійних особистостей. Як наслідок, виникає потреба формування у студентівіноземців української мовленнєвої компетенції, що $\epsilon$ неможливим без їхньої мовної підготовки.

Для студентів-іноземців, що вивчають дисципліни рідною (англійською) мовою, українська засвоюється для комунікації в соціокультурному оточенні країни, в якій вони здобувають професійну освіту. Основним завданням викладача української мови є вироблення в них умінь і навичок комунікативно вправно користуватися засобами української мови як іноземної в різних життєвих ситуаціях та у своїй професійній діяльності, адекватно сприймати діалогічне мовлення на слух, вести діалог.

Діалогічне мовлення, як основний вид мовленнєвої діяльності при вивченні української мови як іноземної, є одним із його базових елементів. Кожен із учасників діалогування виступає в ролі як мовця, так і слухача, а відтак повинен вміти розпочинати діалог, реагувати на репліки співрозмовника й спонукати його до продовження розмови.

Навчання діалогічного мовлення у медичному вузі передбачає також вміння вільно володіти професійною лексикою та обмінюватися знаннями 3 медичних предметів, обговорювати теми, дискутувати з їх приводу.

Проблема формування навичок діалогічного мовлення студентів-іноземців є актуальною. Л. Солодар, Г. Швець, Л. Ананьєва окреслили особливості навчання діалогічного мовлення на початковому (підготовчому) етапі. Значна кількість учених (Е. Шубін, В. Скалкін, В. Артеомов тощо) займалися питанням діалогічного мовлення загалом. Як наслідок дослідження системи діалогічного мовлення іноземних студентів-медиків недостатньо висвітлені у сучасній лінгводидактиці.

Мета дослідження - запропонувати методику формування в іноземних студентів медичного профілю умінь і навичок діалогування, наголосити на потребі його засвоєння для орієнтації в українському мовленнєвому середовищі.
Методи дослідження: спостереження, опис, узагальнення, пояснення, аналіз.

Результати дослідження. Відповідно до програми курсу «Українська мова як іноземна» ДВНЗ «Тернопільський державний медичний університет імені I. Я. Горбачевського МОЗ України», основними положеннями навчання української мови як іноземної є: 1) організація навчального процесу з метою формування в іноземних студентів комунікативної компетентності на основі цілісного комплексу вмінь та навичок ефективного спілкування в побутовій, суспільно-політичній, соціокультурній і навчальнопрофесійній сферах; 2) оволодіння мовленнєвою та комунікативною компетенцією згідно з основними положеннями теорії мовленнєвої діяльності й комунікації; 3) організація навчальної діяльності відповідно до комунікативних і пізнавальних потреб студентів; 4) професійно орієнтований характер навчальної дисципліни «Українська мова як іноземна»; 5) функціонально-комунікативний підхід до відбору мовного матеріалу; 6) взаємодія викладача та студента як активних учасників навчального процесу; 7) позиціонування інокомуніканта як суб’єкта навчання. Основною метою вивчення української мови іноземцями вважаємо комунікативну, що полягає у розумінні мови як засобу спілкування у розмовно-побутовій та професійній сфері. Відповідно до цього, процес вивчення української мови як іноземної ВНЗ спрямований на «практичне володіння мовою на рівні, достатньому для здійснення пізнавальної діяльності в соціокультурній і навчальнопрофесійній сферах, що реалізується за допомогою комплексного підходу до підготовки майбутніх спеціалістів і передбачає взаємодію комунікативних, освітніх і виховних цілей» [4].

Система навчання українського діалогічного мовлення іноземців передбачає засвоєння мовно-мовленнєвих знань з української мови та формування комунікативних умінь і навичок, актуальних для послуговування у навколишньому українському мовленнєвому середовищі. Цей процес на початковому етапі передбачає вироблення «умінь сприйняти почуте, зрозуміти, відтворити його і продукувати діалогічні висловлювання - репліки, єдності, тексти, що відповідають мовленнєвим потребам іноземних студентів-медиків» [3]. Пропонуємо систему роботи, спрямовану на формування навичок діалогічного мовлення студентів медичних спеціальностей під час вивчення курсу української 
мови як іноземної, зокрема теми «Погода. Явища природи», що включає в себе відповідні методи, прийоми і засоби навчання.

Опрацювання запропонованої теми, яку студенти вивчають на другому курсі навчання (у них уже наявний відповідний словниковий запас, певні граматичні навички), варто розпочати із виразного читання тестів, яке супроводжуватиме використання презентації мультимедіа-проектора на відповідну тематику. Саме такий прийом допоможе студентаміноземцям відчути красу українського слова, його милозвучність; важливим при цьому є підбір тестів, зміст яких повинен бути зрозумілим. Пропонуємо використати наступну розповідь.

\section{«Погода»}

Усі ми, вирушаючи до університету чи на роботу, цікавимося, якою буде погода. Виглядаємо у вікно, $\epsilon$ опади чи немає, дивимося на термометр - холодно чи тепло, намагаємося передбачити, який буде день. Отже, погода може змінюватися за короткий проміжок часу. Для нас вона може бути гарною або поганою, але для спеціаліста поняття погода містить в собі температуру повітря, швидкість, силу і напрям вітру, хмарність та опади.

Всі ці показники можуть змінюватися у часі та у просторі. Це означає, якщо в одній місцевості сухо, тепло і сонячно, то за кілька десятків кілометрів від неї може бути холодно і волого, а через кілька годин все знову зміниться.

В Україні зима - звичайно холодна пора року. Часто йде сніг, бувають заметілі, ріки замерзають. Узимку сонце рано сідає і пізно встає, особливо в грудні і січні. Дні короткі, небо часто буває сірим.

Весною поступово стає тепло. Сонце світить яскравіше, небо стає безхмарним. Часто йдуть дощі.

За весною надходить літо. Погода стає усе тепліша, а іноді буває спека. Небо блакитне і безхмарне, але іноді бувають грози з громом і блискавками.

У вересні приходить осінь. Це теж прекрасна пора року, коли погода усе ще тепла, а листя жовтіє. Але до кінця жовтня погода стає усе холоднішою. Часті дощі і тумани. У небі висять низькі і важкі хмари.

Після читання тексту викладач проводить бесіду зі студентами.

Для кращого розуміння й засвоєння навчального матеріалу варто використати роздатковий матеріал (пропонуємо таблицю слів, за допомогою якої зможемо описати погоду та природні явища):

\begin{tabular}{|c|c|}
\hline Погода. Явища погоди & $\begin{array}{c}\text { Дієслова, які } \\
\text { вживаються зі словом }\end{array}$ \\
\hline $\begin{array}{l}\text { погода: відмінна, чудова, не- } \\
\text { сприятлива, спекотна, огид- } \\
\text { на, сувора, погана, дуже хо- } \\
\text { лодна, вогка, тепла, волога, } \\
\text { задушлива, помірна, непе- } \\
\text { редбачувана, мінлива, мороз- } \\
\text { на, грозова, не по сезону }\end{array}$ & $\begin{array}{l}\text { погіршуватися, зали- } \\
\text { шатися такою ж, по- } \\
\text { кращитися, потепліти }\end{array}$ \\
\hline $\begin{array}{l}\text { дощ: злива, проливний, } \\
\text { сильний, затяжний, слабкий, } \\
\text { місцями, переривчастий, без- } \\
\text { перервний }\end{array}$ & $\begin{array}{l}\text { бити, капати, падати, } \\
\text { іти, дощить }\end{array}$ \\
\hline $\begin{array}{l}\text { сніг: снігопад, хуртовина, } \\
\text { сильний, легкий, мокрий, } \\
\text { скрипучий, невеликий }\end{array}$ & $\begin{array}{l}\text { падати, покривати, } \\
\text { кружляти, мести, то- } \\
\text { питися }\end{array}$ \\
\hline $\begin{array}{l}\text { туман: густий, сильний, } \\
\text { щільний, слабкий, білий }\end{array}$ & $\begin{array}{l}\text { бути оповитим, по- } \\
\text { критим, пробиватися } \\
\text { крізь туман, лежати, } \\
\text { опускатися, огортати } \\
\end{array}$ \\
\hline $\begin{array}{l}\text { небо: чисте, безхмарне, со- } \\
\text { нячне, в хмарах, затягнуте } \\
\text { хмарами, похмуре, зоряне, } \\
\text { блакитне }\end{array}$ & $\begin{array}{l}\text { світлішати, затягува- } \\
\text { тися хмарами, прояс- } \\
\text { нюватися, темніти }\end{array}$ \\
\hline $\begin{array}{l}\text { вітер: штормовий, сильний, } \\
\text { помірний, невеликий, порив- } \\
\text { частий, пронизливий, різкий, } \\
\text { свіжий, прохолодний, пів- } \\
\text { нічний, південний, західний, } \\
\text { північно-східний, південно- } \\
\text { східний, східний, північно- } \\
\text { західний, південно-західний }\end{array}$ & $\begin{array}{l}\text { дути, завивати, зрос- } \\
\text { тати, вщухати, припи- } \\
\text { нятися }\end{array}$ \\
\hline
\end{tabular}

Такий вид роботи допоможе збагатити словниковий запас студентів і поглибити мовні знання.

Продовженням роботи над формуванням діалогічного мовлення іноземних студентів-медиків $\epsilon$ виконання розроблених ними завдань.

1. Поставити запитання, що стосуються опису погоди, і відповісти на них. Такий метод роботи стимулює студентів до продукування діалогічних реплік і формування навичок діалогічного мовлення.

2. Створити діалогічні єдності за допомогою продукування реплік-відповідей на поставлені викладачем репліки-запитання: ПИТАННЯ ПРО ПОГОДУ. Підкреслимо, що робота над продукуванням реплік-відповідей на поставлені запитання дає можливість створити монологічний текст. Так відбувається тісний зв’язок між формуванням українського діалогічного і одночасно монологічного мовлення.

3. Скласти діалогічні єдності за моделями: «запитання - відповідь», «пропозиція - згода/незгода», 
«інформація/повідомлення - сприймання/несприймання інформації/повідомлення», «захоплення розчарування» тощо.

4. Побудувати діалогічні тексти (5-6 реплік) про погоду в Україні, у рідній країні студента.

Для методики викладання української мови загалом, а також для формування діалогічного мовлення, велике значення має розуміння важливості визначення раціональної системи вправ, в основі якої лежить набуття тих чи інших мовленнєвих навичок і вмінь. Враховуючи педагогічні принципи систематичності та послідовності, наступності, активності, зв’язку теорії з практикою, навчання з життям, навчання - 3 вихованням, пропонуємо студентам виконати такі завдання.

Завдання 1. Читайте.

1. - Сніг падає?

- Нi, сніг припинився.

- Думаю, погода зміниться.

- Я теж так думаю.

2. - Яка сьогодні погода?

- Сьогодні дуже тепло.

- А температура повітря?

- + $21{ }^{\circ} \mathrm{C}$ градус. Без вітру. Хоча на вечір прогнозують дощ.

3. - Сьогодні мороз?

- Так. П’ятнадцять градусів $\left(-15^{\circ} \mathrm{C}\right)$ нижче нуля.

- Не забудьте одягнути тепле пальто.

- Не забуду.

4. - Як там сьогодні на вулиці? Погода гарна?

- Так, погода гарна.

- Підемо гуляти.

- Із задоволенням.

5. - Цікаво, чи прогнозують на завтра опади?

- Здається, так. Сніг і сильний вітер.

- А температура повітря?

- Близько десяти нижче нуля.

6. - Сьогодні дуже гарна погода. Хоча ще досить рано, але вже дуже тепло. Немає вітру. Небо чисте.

- Так, справді, тепло. На траві ще є роса, тому я думаю, що день сьогодні буде спекотним.

- Сподіваюсь так і буде. Бо дощі вже всім набридли. Хочеться тепла.

- Авжеж.

7. - Ну і нічка була сьогодні. Всю ніч падав рясний дощ. Гриміло. Блискало.

- Так. Але зранку погода змінилася. Теплішає. Немає вітру.

- Але небо похмуре. Здається, знову дощитиме.

- Можливо, тому не забудь узяти з собою парасолю.
8. - Яка була погода у Тернополі минулого тижня? - Було сонячно, але прохолодно. А у Львові?

- Здається, у нас було тепліше, але йшов дощ.

Завдання 2. Відповідайте.

1. Яка погода сьогодні у Тернополі? 2. Яку погоду прогнозують на завтра? 3. Яка погода була вчора? 4. Яка погода у Вас на Батьківщині? 5. Чи прогнозують на сьогодні опади? 6. Чи є вітер на вулиці? 7. Ви знаєте прогноз погоди на завтра? 8. Чи був вчора вітер з сильним дощем? 9. Чи падає сніг надворі? 10. Яка погода в Україні влітку? 11. Яка погода влітку у Вашій країні? 12. Яка погода в Україні восени? 13. Яка погода восени у Вашій країні? 14. Яка погода в Україні взимку? 15. Яка погода взимку у Вашій країні? 16. Яка погода в Україні навесні? 17. Яка погода навесні у Вашій країні?

Завдання 3. Доповніть діалоги.

1. $-\ldots$ ?

- Погода в Україні залежить від пори року.

$-\ldots$ ?

- Для ранньої весни характерна нестійка погода.

2. - Коли наступає зима в Україні?

$-\ldots$.

- Яка це пора року?

$-\ldots$.

3. $-\ldots$ ?

- На початку осені зазвичай панує суха, сонячна погода.

$-\ldots$ ?

- Так, часто буває бабине літо?

4. - Коли влітку найчастіше падають дощі?

$-\ldots$.

- Чи бувають грози, зливи в цей період?

$-\ldots$.

5.-...?

- Так, у вересні - жовтні бувають заморозки.

$-\ldots$ ?

- Їх спричиняють холодні маси.

6.-...?

- Весною підвищується температура повітря.

$-\ldots$ ?

- Іноді бувають заморозки.

7. - Яка погода взимку в Україні?

$-\ldots$.

- Чи подобається тобі зима в Україні?

$-\ldots$.

8. $-\ldots$ ?

- Найчастіше тумани бувають восени.

$-\ldots$ ?

- Так, після туманів часто йдуть дощі. 
Завдання 4. Продовжіть речення.

1. Погода в Україні залежить .... . 2. На початку осені ... . 3. Українська зима ... . 4. У другій половині осені ... . 5. Для ранньої весни характерна .... . 6. Літо - ... . 7. Холодні маси у вересні - жовтні ... . 8. Часто під впливом теплих повітряних мас ... . 9. Навесні починаються ... .10. На півдні літо настає ... . 11. Зима найхолодніша пора року, якій властива ... . . 12. В Україні пори року ... . 13. Дні стають ... . 14. Максимум опадів припадає на червень - липень, часто.

\section{Список літератури}

1. Концепції мовної освіти іноземців у вищих навчальних закладах України. - URL : http: // http://dspace.univer. kharkov.ua/handle/123456789/5396.

2. Українська мова як іноземна : посібник. - Тернопіль, 2017. - 328 c.

3. Українська мова як іноземна: Робоча програма для іноземних студентів вищих навчальних закладів МОЗ України. Галузь знань: 22 «Охорона здоров’я». - Тернопіль, 2019. - 36 с. - URL : http: // https://moodle.tdmu. edu.ua/mod/resource/view.php?id=152209.

4. Шеремета Л. П. Використання творчості Т. Г. Шевченка на початковому етапі навчання діалогічного мов-

\section{References}

1. Kontseptsii movnoi osvity inozemtsiv u vyshchykh navchalnykh zakladakh Ukrainy [Concepts of language education of foreigners in higner educational establishments in Ukraine]. Retrieved from: http://dspace.univer.kharkov.ua/ handle/123456789/5396 [in Ukrainian].

2. Ukrainska mova yak inozemna: posibnyk [Ukrainian as a foreign language: a manual]. Ternopil [in Ukrainian].

3. Ukrainska mova yak inozemna: Robocha prohrama dlia inozemnykh studentiv vyshchykh navchalnykh zakladiv MOZ Ukrainy. Haluz znan: 22 “Okhorona zdorovia” [Ukrainian as a foreign language: Working program for foreign students of higher educational institutions of the Ministry of Health of Ukraine]. Retrieved from: http: // https:// moodle.tdmu.edu.ua/mod/resource/view.php?id=152209 [in Ukrainian].
Висновки та перспективи подальших досліджень. Система запропонованих вправ сприяє активному формуванню українського усного діалогічного мовлення іноземних студентів медичних навчальних закладів.

Виконане дослідження не претендує на остаточне розв'язання піднятої проблеми, оскільки цілком актуальним і перспективним упродовж опрацювання курсу «Українська мова як іноземна» є вироблення специфічних лінгводидактичних напрямів, методів і прийомів, що стосуються формування українського усного діалогічного мовленні іноземних студентів-медиків.

лення іноземних студентів-медиків / Л. П. Шеремета // Науковий вісник Ужгородського національного університету. Серія «Педагогіка. Соціальна робота». - 2014. № 33. - С. 212-215.

5. Шеремета Л. П. Система вправ для навчання діалогічного мовлення іноземних студентів-медиків / Л. П. Шеремета // Українська професійна мова : історія і сучасність : збірник матеріалів регіональної наук.-практ. конф. - Тернопіль : ТДМУ, 2014. - С. 31-33.

4. Sheremeta, L.P (2014). Vykorystannia tvorchosti T.H. Shevchenka na pochatkovomu etapi navchannia dialohichnoho movlennia inozemnykh studentiv-medykiv [The use of creativity of T.H. Shevchenko at the initial stage of teaching dialogic speech of foreign medical students]. Sheremeta L.P. Naukovyi visnyk Uzhhorodskoho natsionalnoho universytetu. Seriia "Pedahohika. Sotsialna robota”-Scientific Bulletin of Uzhhorod University. Series: Pedagogy. Social Work, 33, 212-215 [in Ukrainian].

5. Sheremeta, L.P. Systema vprav dlia navchannia dialohichnoho movlennia inozemnykh studentiv-medykiv [A system of exercises for the teaching of dialogic speech to foreign medical students]. Ukrainian Professional Language: History and Modernity: Collection of Materials of the Regional Scientific and Practical Conference. Ternopil: TSMU [in Ukrainian]. 